\title{
VI. Decontexualizing Female Criminality: Treating Abused Women in Prison in the United States
}

\author{
Susan MARCUS-MENDOZA and Erin WRIGHT
}

\section{INTRODUCTION}

The majority of women prisoners in the United States have been victims of physical, sexual or emotional abuse prior to their incarceration. Although research has shown the connection between abuse and criminality, and innovative feminist interventions exist to address the psychological consequences of abuse, most prisons do not utilize these. This article examines the effects of prior abuse on women's criminality, the importance of considering this context when designing treatment for incarcerated women, and the contradictions that arise in those prisons that do offer a feminist intervention.

\section{THE PSYCHOLOGICAL EFFECTS OF VIOLENCE AGAINST WOMEN}

Research has shown that economic marginalization, substance abuse, sexual and physical abuse, and parenting without adequate financial resources can lead to criminality (Chesney-Lind, 1997; Owen, 1998; Velasquez, 1998). Perhaps the most important of these factors are emotional, physical, and sexual abuse, which may lead to low self-esteem, substance abuse, and juvenile delinquency. The majority of incarcerated women in the United States have reported experiencing one or more types of abuse (Browne et al., 1999; Marcus-Mendoza et al., 1994; Owen, 1998). Zlotnick (1997) found that 78 percent to 85 percent of women inmates had experienced at least one traumatic event compared to 69 percent of women in the general population. According to Walker (1994), this is a higher

Feminism \& Psychology @ 2004 SAGE (London, Thousand Oaks and New Delhi) Vol. 14(2): 250-255; 0959-3535

DOI: $10.1177 / 0959-353504042179$ 
rate than that experienced by women in the general population (50 percent), women in outpatient therapy (68 percent), or hospitalized women and men (50 percent to 80 percent). Further it has been argued that abuse is a precursor to criminality. In a study of sexually abused and non-abused children (aged 0-11 to 33 years) Widom's (2000) findings showed that abused girls were significantly more likely than non-abused girls to:

1. become runaways to escape an abusive environment;

2. score lower on intelligence and reading tests;

3. be raised by substance-abusing parents;

4. lack social and psychological resources; and

5. engage in criminal behavior.

Belknap and Holsinger (1998) identified a pattern emerging from the mainstream research on 'delinquent' girls in the 1980s and 1990s: childhood victimization results in 'delinquent behavior' such as running away, drug and alcohol misuse, prostitution, selling drugs, and robbery to survive and to feed drug habits. According to Zaplin (1998), this cycle of events leads to emotional stress, selfhatred, anxiety, depression, and aggressive and impulsive behaviors, with girls at risk of not being able to develop empathic or caring attitudes for themselves or others. Such research suggests that violence and crime leads to more violence and to later incarceration, and promotes a familiar 'cycle of blame' in which both the responsibility for the origins and the solution for disrupting 'delinquent' behaviour are located within the young women themselves (Gilligan et al., 1991; Hannah-Moffat, this issue). Early histories have been linked to consequences for adult women, where 'mentally ill' women in state prisons (64 percent) and federal prisons (78 percent) had a history of physical or mental abuse (United States General Accounting Office, 1999), and Zlotnick (1997) reported that Post Traumatic Stress Syndrome rates among women prisoners are twice that of women in the general population. It is important that the impact of abuse histories on women's well-being be acknowledged and treated in prison.

\section{INTERVENTIONS FOR WOMEN IN PRISON}

In a recent US government report, Ritchie (2000) called for gender-specific interventions that empower women and lead to positive life changes once they are released. Scholars and practitioners have developed feminist-based interventions for women inmates which take into account the context of women's lives. Relational-cultural theory posits that healthy growth occurs in connection, and that the goal of growth is not separation but healthy relationships characterized by mutual empathy and empowerment (Jordan and Hartling, 2002). Disconnections are harmful when a woman is unable to voice her feelings due to a power differential, or when she encounters indifference, denial or injury. Disconnections also occur when sexism, racism, heterosexism, categorizing, and stereo- 
typing keep women from engaging in growth-promoting relationships. Brown's (1996) feminist therapy encourages resistance, personal integrity, and selfesteem. Resistance is not seen as unfeminine behavior, but as a healthy response to the social and political context. Unfortunately, this contrasts sharply with correctional systems, which punish resistance. Therefore, feminist therapists are caught in a paradox where they attempt to empower women while also helping them survive in, and conform to, the oppressive prison environment.

However, prison is not an ideal environment for feminist therapy. Feminist scholars assert that prison often promotes relational disconnection and violation, producing a microcosm of patriarchal society inside prison walls and recreating dynamics similar to those experienced during prisoners' violent past. This creates further challenges for feminist therapists (Covington, 1998; Marcus-Mendoza et al., 1998) who may be positioned in two conflicting but co-existing roles. For instance, in correctional boot camps, the same staff member may be drilling and inspecting a woman one minute and in the next minute be in the role of therapist with the same woman. This creates the same confusing and traumatic dynamic as that which occurred in a past 'intimate' and abusive relationship (incest, battering, date rape) and can thus be similarly traumatizing (Marcus-Mendoza et al., 1998). Therefore, prison interventions must often address traumatic issues in a traumatic environment.

Despite these challenges, effective feminist interventions for abused women are utilized in some prisons. For instance, Merriam (1998) uses art therapy to help women express feelings related to trauma through the safe boundaries of their artwork. She argues that art therapy empowers women by giving them a voice and providing an outlet to express strong emotions in the prison setting where emotional expression is unsafe. Covington (1998) uses relational theory to work with incarcerated women with histories of substance misuse and abuse. Zaplin and Dougherty (1998), in discussing programming for mothers in prison, stress interventions for problems traditionally experienced by abused and battered women, particularly stress management, substance abuse counseling, coping skills, and parenting skills. Bradley and Moschella (1998), who argue that some prostitutes are engaged in a continued exploitation of their bodies that started in childhood, understand the consequences of sexual abuse as central to their therapeutic work. As the small number of studies above indicates, despite the clearly demonstrated need for feminist treatment for women, these interventions are not widely used in the United States (Belknap, 2003). Morash et al. (1998) surveyed departments of corrections and prisons in all states. Only three of the 52 states had measures designed to assess women's needs. Most programming was not designed specifically for women, and only 16 states had innovative programming. However, prison administrators suggested that victimization programs that focused on enhancing self-esteem, empowerment, and self-sufficiency were more likely to be successful than those programmes which did not have such a focus. This again reinforces the need for feminist treatment that considers women's histories of abuse. 
It is important to note that some correctional researchers who are strong advocates for better programming for women do not agree with linking abuse and other contextual events in correctional programming. Holtfreter and Morash (2003) minimize the importance of context and focus on criminogenic risk factors empirically linked to recidivism, as measured by standardized instruments. However, as noted in many of the other articles in this Feminism \& Psychology special feature, these instruments do not accurately account for many of women's past experiences that cannot be deemed risk factors and may not be appropriately addressed.

From a feminist perspective, it is counterproductive to treat each issue as though it is not part of the larger context of women's lives. As discussed earlier, Widom (2000) and others have shown a link from abuse to criminality and to problems cited as risk factors. In fact, Holtfreter and Morash (2003) found that the group of women in their study who were at highest risk for recidivism reported more substance abuse, parenting needs, and mental health needs - all common consequences of physical, sexual, and emotional abuse. To effectively help incarcerated women, it is important to acknowledge that abuse and other life experiences are often the context in which these problems develop. Decontexualizing the problems of women prisoners leads to treatment that may only address the symptoms while ignoring the underlying experiences and psychological trauma.

\section{CONCLUSION}

Appropriate and effective prison programming for women must take into account these contextual variables. Although there are feminist programs specifically designed for abused, incarcerated women, they are not available in most prisons. It is imperative that scholars and correctional systems recognize the importance of the context of female criminality and its role in effective treatment.

\section{REFERENCES}

Belknap, J. (2003) 'Responding to the Needs of Women Prisoners', in S. Sharp (ed.) The Incarcerated Woman: Rehabilitative Programming in Women's Prisons, pp. 93-117. Upper Saddle River, NJ: Prentice Hall.

Belknap, J. and Holsinger, K. (1998) 'An Overview of Delinquent Girls: How Theory and Practice have Failed and the Need for Innovative Changes', in R. Zaplin (ed.) Female Offenders: Critical Perspectives and Effective Interventions, pp. 31-64. Gaithersburg, MD: Aspen Publishers.

Bradley, L. and Moschella, L. (1998) 'Programs that Work: Working with Prostitutes', in R. Zaplin (ed.) Female Offenders: Critical Perspectives and Effective Interventions, pp. 349-60. Gaithersburg, MD: Aspen Publishers. 
Brown, L.S. (1996) Subversive Dialogues: Theory in Feminist Therapy. New York: Basic Books.

Browne, A., Miller, B. and Maguin, E. (1999) 'Prevalence and Severity of Lifetime Physical and Sexual Victimization among Incarcerated Women', International Journal of Law and Psychiatry 22 (3-4): 301-22.

Chesney-Lind, M. (1997) The Female Offender: Girls, Women, and Crime. Thousand Oaks, CA: Sage.

Covington, S.S. (1998) 'The Relational Theory of Women's Psychological Development: Implications for the Criminal Justice System', in R. Zaplin (ed.) Female Offenders: Critical Perspectives and Effective Interventions, pp. 113-32. Gaithersburg, MD: Aspen Publishers.

Gilligan, C., Rogers, A. and Toman, D. (eds) (1991) Women, Girls and Psychotherapy: Reframing Resistance. Binghampton, NY: Harrington Park Press.

Holtfreter, K. and Morash, M. (2003) 'The Needs of Women Offenders: Implications for Correctional Programming', Women \& Criminal Justice 14 (2/3): 137-60.

Jordan, J. and Hartling, L. (2002) 'New Developments in Relational-Cultural Theory', in M. Ballou and L. Brown (eds) Rethinking Mental Health and Disorder: Feminist Perspectives, pp. 48-70. New York: The Guilford Press.

Marcus-Mendoza, S.T., Klein-Saffran, J. and Lutze, F. (1998) 'A Feminist Examination of Boot Camp Prison Programs for Women', Women \& Therapy 21(1): 173-85.

Marcus-Mendoza, S.T., Sargent, E. and Chong Ho, Y. (1994) 'Changing Perceptions of the Etiology of Crime: The Relationship between Abuse and Female Criminology', Journal of the Oklahoma Criminal Justice Research Consortium. 1: 13-23.

Merriam, B. (1998) 'To Find a Voice: Art Therapy in a Women's Prison', Women \& Therapy 21(1): 157-71.

Morash, M., Bynum, T.S. and Koons, B.A. (1998) Women Offenders: Programming Needs and Promising Approaches, Research in Brief. Washington, DC: National Institute of Justice (NCJ 171668).

Owen, B. (1998) In the Mix: Struggle and Survival in a Women's Prison. Albany, NY: State University of New York Press.

Ritchie, B.E. (2000) 'Exploring the Link between Violence against Women and Women's Involvement in Illegal Activity', in B. Ritchie, K. Tsenin and C. Widom, Research on Women and Girls in the Justice System, Research Forum, pp. 1-13. Washington, DC: National Institute of Justice (NCJ 180973). Available at: http://www.ncjrs.org/ pdffiles1/nij/180973.pdf

United States General Accounting Office (1999) Women in Prison: Issues and Challenges confronting the U.S. correctional systems, (GAO/GGD-00-22). Washington, DC: United States General Accounting Office.

Velasquez, A. (1998) 'An Integrated Systems Approach to Program Development and Implementation', pp. 291-306 in R. Zaplin (ed.) Female Offenders: Critical Perspectives and Effective Interventions. Gaithersburg, MD: Aspen Publishers.

Walker, L.E.A. (1994) Abused Women and Survivor Therapy. Washington, DC: American Psychological Association.

Widom, C.S. (2000) 'Childhood Victimization and the Derailment of Girls and Women to the Criminal Justice System', in B. Ritchie, K. Tsenin and C. Widom, Research on Women and Girls in the Justice System, Research Forum, pp. 27-36. Washington, DC: National Institute of Justice (NCJ 180973). Available at: http://www.ncjrs.org/ pdffiles1/nij/180973.pdf 
Zaplin, R. (1998) 'Female Offenders: A Systems Perspective', in R. Zaplin (ed.) Female Offenders: Critical Perspectives and Effective Interventions, pp. 65-80. Gaithersburg, MD: Aspen Publishers.

Zaplin, R. and Dougherty, J. (1998) 'Programs that Work: Mothers', in R. Zaplin (ed.) Female Offenders: Critical Perspectives and Effective Interventions, pp. 331-48. Gaithersburg, MD: Aspen Publishers.

Zlotnick, C. (1997) 'Posttraumatic Stress Disorder (PTSD), PTSD Comorbidity, and Childhood Abuse among Incarcerated Women', The Journal of Nervous and Mental Disease 185(12): 761-3.

Susan MARCUS-MENDOZA is an Associate Professor of Human Relations and Women's Studies and the Chair of the Department of Human Relations at the University of Oklahoma, USA. She is also a licensed psychologist. Previously, Susan was the chief psychologist at a federal prison camp for women.

ADDRESS: Dr Susan MARCUS-MENDOZA, Department of Human Relations, University of Oklahoma, 601 Elm Ave, Norman, OK 73019, USA.

[email: smmendoza@ou.edu]

Erin WRIGHT graduated from Providence College USA in 1998 with a degree in Human Relations and foci in African American studies and Women's Studies. In 2000 she received a master's degree in Human Relations, with a focus in Women's Studies. She currently resides in Indiana, where she is obtaining her JD from the University of Notre Dame.

ADDRESS: Erin WRIGHT, 5825 Shawnee Ct. Apt 1A, Mishawaka, IN 46545, USA.

[email: emwr1@yahoo.com] 